\title{
The challenges facing sustainable and adaptive groundwater management in South Africa
}

\author{
Kathrin Knüppe \\ Institute of Environmental Systems Research, University of Osnabrück, Barbarastrasse 12, 49069 Osnabrück, Germany
}

\begin{abstract}
Long-term population growth and economic development are placing ever-increasing pressure on South Africa's freshwater supply. On the basis of the current climate change predictions, which often entail uncertain consequences for aquifer systems and the associated groundwater goods and services, it is expected that the stress on water will increase even further. Currently, South Africa's groundwater governance regime does not provide the capacity to assure effective and sustainable resource regulation and allocation. To date, the management of groundwater is hampered by a variety of uncertainties, such as global climate change and socio-economic growth, as well as ineffective governance structures affecting resource use, regulation, protection and the implementation of alternative strategies needed to achieve sustainable management. This paper presents the results of a qualitative assessment of interviews conducted with experts in South Africa. Four key challenges are identified to the development of adaptive and sustainable groundwater management and the successful implementation of current water legislation in South Africa. These are: the undervaluation of groundwater importance and significance; the need for expertise and information at all scales; the centralisation of power; and the disregard of ecosystems and the associated goods and services. As a means to tackle these challenges, it has been assumed that the concept of adaptive water management represents a suitable approach to governing groundwater resources, by taking into account complex system linkages between hydrogeological, political, socio-economic and environmental domains. Supporting principles, such as tools for cooperation, participation and information networks, have been developed to facilitate the implementation of adaptive water management approaches and hence to achieve institutional change in the political arena of groundwater management.
\end{abstract}

Keywords: groundwater, South Africa, ecosystem services, adaptive water management, qualitative assessment

\section{Introduction}

South Africa is a water-stressed, semi-arid country with an average annual rainfall of around $500 \mathrm{~mm}$, which is less than $60 \%$ of the world average (Mukheibir and Sparks, 2005). The financial, human and ecological impacts of global and local changes to climate are already evident in South Africa, particularly where water resources are under the greatest pressure (Schulze, 2005).

On a global scale, groundwater is an essential freshwater resource for both socio-economic and environmental systems. It provides a wide range of diverse goods and functions, described here as ecosystem services, namely, the 'conditions and processes through which natural systems and the species that make them up sustain and fulfil human life' (Daily, 1997, p. 3). In many parts of South Africa groundwater allocation and protection has become an important issue, as groundwater represents an important source of freshwater (Münch and Conrad, 2007). It has the potential to play a strategic role in providing water for drinking and sanitation, supporting agricultural irrigation schemes and industrial uses, reducing poverty and disease, and maintaining important aquatic and terrestrial ecosystems. The South African hydrogeological community has claimed that groundwater is currently underutilised

\footnotetext{
* To whom all correspondence should be addressed.

푱 +49 541969 2429; fax: +49 541969 2368;

e-mail: Kathrin.Knueppe@usf.uni-osnabrueck.de

Received 27 April 2010; accepted in revised form 8 November 2010.
}

and undervalued in many parts of the country. Accordingly, groundwater management is neither strongly emphasised in national water legislation, nor is it implemented where it is needed.

The total harvest potential of aquifer systems in South Africa was estimated to be $19000 \mathrm{~m} \cdot \mathrm{m}^{3} / \mathrm{a}$, approximately $6000 \mathrm{~m} \cdot \mathrm{m}^{3}$ of which is groundwater that could be sustainably used each year without depleting the aquifers. In recent times, only around $1100 \mathrm{~m} . \mathrm{m}^{3} / \mathrm{a}$ has been used throughout the country (DWAF, 2004a).

Most of the constraints on sustainable groundwater management observed globally can be linked to failures in governance structures (e.g., Bakker et al., 2008; Rogers and Hall, 2007). According to Loucks (2000, p. 3), sustainability in water resource management means: 'Water resource systems that are managed to satisfy the changing demands put on them, now and on into the future, without system degradation.' The most challenging hurdles that global groundwater governance regimes must overcome are institutional and political factors, including fragmented and overlapping jurisdictions and responsibilities, competing priorities, traditional approaches, rights and water pricing systems, and diverging opinions (Council of Canadian Academies, 2009). Furthermore, the lack of adequate knowledge and physical data pertaining to aquifer characteristics and behaviour such as recharge, discharge, base flow and aquiferdependent ecosystems, as well as important linkages between groundwater ecosystem services and human well-being, render resource planning and management challenging and unpredictable. These problems can also be observed in South Africa's groundwater governance systems. According to Seward (2010), 
the implementation of novel groundwater policies in South Africa needs a right balance, between simple concepts which are easily communicated to stakeholders, on the one side, and management approaches that are theoretically established but not always easy to comprehend, on the other side.

This paper identifies challenges and hurdles impeding sustainable and efficient groundwater use in South Africa, considering both national and local perspectives. At the same time, the paper represents a contribution to the small existing volume of academic literature on groundwater governance structures, alternative management approaches and resource protection in South Africa (for example, Parsons and Tredoux, 1995; Braune and Reynders, 1998; Seward et al., 2006; Colvin and Saayman, 2007; Braune and Xu, 2008; Braune and Xu, 2009).

The paper is divided into 5 sections. The first section provides a general overview of the challenges facing groundwater governance globally, including natural and anthropogenic resource impacts. In the second section the current status of South Africa's groundwater development and management is discussed. In the third section results derived from expert interviews are summarised to provide insights into the challenges to management and the constraints on sustainable and efficient groundwater use. An argument is made for the need to introduce more flexible and holistic management concepts in the governance of groundwater resources in South Africa, by pointing out the risks and uncertainties in relation to groundwater in the fourth section. The adaptive management approach is assumed to provide an adequate basis for recommendations, including guiding principles for South Africa's water managers. Finally, a conclusion is provided along with an outlook towards development and implementation of adaptive and integrated groundwater management approaches.

\section{Global governance of groundwater resources}

Groundwater is the Earth's largest accessible store of freshwater (excluding ice sheets and glaciers), and constitutes about $94 \%$ of the world's freshwater resource (Ward and Robinson, 1990). In addition to many geological and ecological functions - such as the transport of dissolved matter below ground, rock weathering and diagenesis, the formation of mineral deposits, supporting water purification and nutrient transportation processes, maintaining spring discharge and providing baseflow to rivers and springs - groundwater is also a key resource for socio-economic development and a strategic buffer resource during periods of drought (Custodio and Llamas, 2001). Often groundwater use has been, and continues to be, carried out with little or no planning or control on the part of public agencies which, as a result, frequently leads to unstructured development in most countries. In general, management practices often ignore problems and fail to take into consideration the integrity of groundwater systems; even in arid and semi-arid regions where groundwater is the main source of freshwater (FAO, 2003). The typical situation in relation to groundwater resource management encompasses socio-economic, ecological, as well as cultural constraints:

- Diagnostic data and information are limited in their availability

- The patterns of use involve a substantial number of individual users

- Changing users perceptions and behaviours towards ecological and sustainable resource allocations often coincides with traditional and cultural attitudes

- Natural and anthropogenic impacts are not very visible and often delayed
- Damages to the resource base can have far-reaching and long-term consequences.

Recently, politicians, water authorities and catchment management organisations throughout the world have progressively come to realise that it is necessary to implement sustainable groundwater management practices now, and that a long-term perspective is required. However, while the scientific knowledge of hydrogeology, and the physical and chemical characteristics of groundwater, is developing continuously, relatively little is as yet known about the institutions and policies that govern the socio-economic aspects of groundwater issues (Mukherji and Shah, 2005).

In most cases, groundwater managers lack the incentives necessary to either intervene or effect change in the usual chain of management processes. Changes in groundwater management are usually only called for once a decline in well yields or water quality affects stakeholders and indispensable services are at risk (Tuinhof et al., 2003a). Changes in aquifers are often recognised too late in the management process for subsequent actions to prevent major damage occurring. Consequently, many groundwater problems are often associated with governance failures rather than the characteristics of physical resources (e.g., Bakker et al., 2008; Rogers and Hall, 2007).

It is assumed that good groundwater governance embodies technical, economic, judicial, social, institutional and administrative structures, and an adequate policy arena that ensures the responsible use and maintenance of groundwater systems and related ecosystem services. According to Turton et al. (2006), governance is described as a process of informed decision-making that enables trade-offs between competing users of a given resource so as to balance protection and use in such a way as to mitigate conflict, enhance security, ensure sustainability and hold government officials accountable for their actions.

The general failures of current groundwater governance globally, and the hurdles to be overcome, can be summarised as follows:

- The intensive use of groundwater resources is of relatively recent origin, dating back no more than half a century in most countries

- The institutional landscape relating to groundwater resources under many government regimes is highly fragmented, and sectoral policies and planning processes are developed in isolation. Cooperation between water managers, scientists, the private sector and the public barely exist or are at an early stage in their development.

- Surface water and groundwater are managed separately. They are not merged in an integrated water management approach within the context of the overall hydrological cycle.

- The invisible nature of groundwater makes understanding of the resource characteristics and behaviour in terms of the geological and hydrogeological settings difficult. Therefore, it requires much sampling, which is costly and cumbersome.

- Groundwater management often lacks the financial and human resources needed for the investigation of the resource characteristics and functions, especially in developing countries, and as a consequence there are shortcomings in terms of reasonable legal provisions and pricing systems

- The dynamic nature of both socio-economic development and predictions of global climate change makes 
groundwater management complex, uncertain and often unpredictable

- Within the last 2 decades the status of private water - coupled to land ownership - changed to public water in many countries.

In the context of groundwater management, good governance needs to involve both issues of resource quantity and quality. Nevertheless, most legal frameworks treat these 2 aspects separately. According to the Council of Canadian Academies (2009), future management requires that decisions concerning resource allocation and use are made transparent through informed public participation and by fully taking into account ecosystem requirements, inter-generational equity and precautionary principles.

\section{Groundwater resources at risk - natural and anthropogenic pressures}

The recent impacts of massive groundwater use in many countries, and the increasing demand for water in the same areas, is often a double-edged sword. On the one hand, groundwater use has given rise to several short and medium-term socioeconomic benefits, by providing a basis for new standards in human well-being, enhancing the diversity of agricultural and industrial production, supporting urban and rural development, providing for improvements in health, and reducing poverty (Mukherji and Shah, 2005). On the other hand, within a very short period of time, many aquifers worldwide and their related ecosystems have been put at risk due to high extraction rates. This mostly results in long-term environmental impacts. In the following discussion, 3 main factors affecting groundwater resources are presented, namely, quantity problems, quality problems, and climate change impacts.

\section{Quantity problems}

The increase in the demand for water frequently results in the overexploitation of aquifers, which in turn leads to the dryingup of wells. Bromley et al. (2001) highlighted the consequences of overexploitation in the long-term. Lowered groundwater tables result in a decoupling of the groundwater and surface water system, including water exchange between rivers, wetlands and springs. Furthermore, lowered groundwater levels lead to increased costs brought about by the need for water pumping, the failure of borehole supplies and saline water intrusion in coastal zones. Danielopol et al. (2003) stated that the critical reduction in the volume of available subsurface water reserves due to the permanent increase in water demand will represent a major environmental trend of the next 25 years. This trend will be exacerbated by global population growth, agricultural practices and landscape alterations, increases in urban areas and in the demand for domestic and public drinking supplies, industrial activities including thermoelectric production, intensive agriculture and mining, and the growing tourism sector.

\section{Quality problems}

Groundwater quality may be impacted upon by liquids (e.g., liquid waste products or oil), by soluble substances in the soil through which water infiltrates, or by bacteria small enough to pass through soil pores (Murray et al., 2007). Often contamination makes groundwater unfit for human use and changes the structures and functioning of ecosystems. The issue of groundwater quality, particularly of shallow groundwater, is becoming more prominent due mainly to increasing populations, contamination caused by anthropogenic activities such as mining (e.g., acidification and increased metal content), urban development (e.g., salinisation, eutrophication, microbial effects), industry (e.g., infiltration of chemicals and toxins), and the intensification of agricultural practices (e.g., sedimentation, infiltration of agro-chemicals and salinisation through irrigation return flows).

\section{Climate change impacts}

Another threat to global groundwater security is temporal and spatial climate variability, including an increase in the occurrence of extreme events such as heavy flooding and frequent periods of drought. As a consequence, the vulnerability of communities, especially poor rural communities, increases, thereby hampering local and national economic growth (Braune and $\mathrm{Xu}, 2009$ ). The most vulnerable areas are those with an annual precipitation rate of $<500 \mathrm{~mm}$, large coastal cities, tropical delta areas and small islands. However, there has not been much research into the impacts of climate change on groundwater resources and ecosystem services. The IPCC declared 'a need to improve understanding and modelling of climate changes related to the hydrological cycle at scales relevant to decision making. Information about the water related impacts of climate change is inadequate - especially with respect to water quality, aquatic ecosystems and groundwater - including their socio-economic dimension' (IPCC, $2008 \mathrm{p}$. 4). It is estimated that climate change will negatively impact groundwater recharge and baseflow in arid and semi-arid areas where recharge depends mainly on rainfall events (Kundzewicz and Döll, 2009; Nyenje and Batelaan, 2009). Groundwater will be less directly, and more slowly, impacted upon than surface water bodies. The main reason for this is that rivers are replenished over a shorter time scale and droughts and floods are quickly reflected in river water levels. Groundwater is affected much more slowly; for instance, after prolonged droughts aquifer levels starts to decline (BGR, 2008).

\section{Groundwater resources in South Africa}

Currently, South Africa's groundwater resources supply approximately $15 \%$ of the total volume of water consumed nationally (DWAF, 2002). More than 280 cities and towns are either wholly or partly dependent on groundwater (Van Tonder, 1999) and groundwater use has increased dramatically, from approximately $684 \mathrm{~m} . \mathrm{m}^{3}$ in 1950 to $1770 \mathrm{~m} . \mathrm{m}^{3}$ in 2004 (Braune and $\mathrm{Xu}, 2008$ ). Approximately $64 \%$ of the groundwater extracted is used for agricultural irrigation purposes, while exploitation for mining and domestic consumption constitutes $8 \%$. The latest data indicate that a total of $235000 \mathrm{~m} . \mathrm{m}^{3} / \mathrm{a}$ is stored underground, and that between $10000 \mathrm{~m}$. and $16000 \mathrm{~m}$. $\mathrm{m}^{3} / \mathrm{a}$ are available for use in an average rainfall year, and 7000 m. $\mathrm{m}^{3} / \mathrm{a}$ in a drought year (DWAF, 2004b).

South Africa's aquifer systems are characterised by a large variety of geological structures and climatic conditions that influence regional hydrogeological settings and, therefore, local extraction rates (Braune and $\mathrm{Xu}, 2008$ ). Roughly 80 to $90 \%$ of local groundwater in South Africa circulates in secondary aquifers consisting mainly of shallow zones dominated by fractured hard rock systems that have virtually no primary porosity (Van Tonder, 1999). 
Groundwater quality and quantity problems in South Africa are mostly related to human activities such as industry and mining, urbanisation and deteriorating standards in wastewater treatment, agricultural drainage, land use patterns and waste disposal, all of which affect both human well-being and ecosystem functioning. For example, high rates of nitrate contamination can be found around urban centres and in the high-density rural settlements of the Northern Cape, Northwest and Limpopo provinces (Tredoux et al., 2009).

\section{Current groundwater management}

During the last 2 decades, the management of water resources in South Africa has undergone substantial change (Braune, 2000). With the democratisation of the country in 1994 came a policy shift towards providing basic services, including water and sanitation services, to all inhabitants as soon as possible (Braune and $\mathrm{Xu}, 2008$ ). The new policy and the management of water resources is based on the principles of equity, efficiency and sustainability, as highlighted in the National Water Act (NWA) of 1998. The Act recognises '...that the ultimate aim of water resource management is to achieve the sustainable use of water of all users,' and furthermore, 'sustainability and equity are identified as central guiding principles in the protection, use, development, conservation, management and control of water resources' (Republic of South Africa, 1998). The Act, which is the principal legal instrument governing all water resources in South Africa, explicitly seeks to promote the efficient and sustainable use of groundwater in the public interest, and to protect aquatic and associated ecosystems and their biological diversity (Braune, 2000). The most important instrument created to achieve these goals is the ecological Reserve. The overall principle of the Reserve is to meet basic human water needs and to protect aquatic ecosystems in order to ensure ecologically sustainable development (Van Wyk et al., 2006). This means that before any water from a river or an aquifer is allocated to any use, the environmental requirements of that particular resource must first be determined and 'reserved' (Muller, 2009).

Until 1998 groundwater was a privately-owned asset coupled to property rights (the riparian system). After the NWA was passed groundwater became a public resource or a resource with shared entitlements to use (Ashton et al., 1999). The progressive reallocation of water to sectors of society that were previously excluded from access to water can help to bridge the gap between the first and second economies, whilst maintaining existing beneficial water uses and encouraging the greater efficiencies needed in a water stressed context. The National Water Resource Strategy (NWRS) provides structural guidelines on how to protect, use, develop, conserve, manage and control all water resources in accordance with the requirements of the policy and law (DWAF, 2004a). The objective of the NWRS is to take the NWA a step further by providing a more practical and detailed document; furthermore, this document (the NWRS) has to be reviewed and rewritten every 5 years.

With the abovementioned change, groundwater was for the first time considered to be part of the hydrological cycle, in which all water should have a consistent status in law, irrespective of where it occurs. Groundwater became part of South Africa's integrated water resource management (IWRM) discourse during the late 1990s, a means to help unlock the full benefits of sustainable water management for poverty reduction and economic growth (World Water Council, 2006). However, this discourse focused primarily on scientific studies of the physical characteristics of aquifers and neglected many of the socio-economic and cultural values associated with groundwater resources (Colvin and Saayman, 2007).

At present, the South African water sector comprises a complex set of institutional relationships, involving a myriad of organisations fulfilling different functions at different political levels. The management of South Africa's water resources and the provision of overall strategies and standards is a national issue and the Department of Water Affairs (DWA, formerly the Department of Water Affairs and Forestry (DWAF)) has overall responsibility for - and authority over - use, allocation, redistribution and protection. Currently the water regime is going through a progressive change process, from a centralised system towards a decentralisation of responsibilities and authorities. To implement policy legislation at a regional and catchment level the DWA regional offices and the catchment management agencies (CMAs) - as far as established - are responsible for the management of all water resources within the 19 water management areas (WMAs; with this number currently being reduced). At a local level, water user associations (WUAs) should be developed as the overall acting agencies or organisations to fulfil the requirements of effective and sustainable water management (DWAF, 2004a).

In 2004 the DWAF developed 'Guidelines for Groundwater Resources Management' to provide clear instructions for the integration of coordinated groundwater management into the IWRM system in effect in the 19 WMAs of South Africa. The guidelines state that groundwater management should not be seen as separate from the management of other water resources in the WMA but as an integral part of a holistic approach to water management.

Twelve years after the passing of the NWA, and in particular following the development of the associated groundwater management guidelines for resource allocation, South Africa's government is still confronted by many obstacles to the achievement of the stated objectives of equity, efficiency and sustainability. Groundwater resources and associated goods and functions are still undervalued and are not being utilised to their full potential. Consequently, the question that needs to be asked is: Why are current groundwater legislations, regulations and guidelines neither being enforced nor soundly implemented on the ground? The motivations behind water legislation in general and groundwater regulations and guidelines in particular are mostly difficult to take into account and implement on a regional level and they are overlooked or neglected by the responsible implementing agencies. This situation is often related to social and cultural constraints, which are related to stakeholders' attitudes and traditional ways of thinking (e.g. property owner of groundwater, pumping rates for irrigation purposes, achievement of water licences, etc.) as well as to uncoordinated and fragmented groundwater governance regimes.

Legislation alone is rarely the only solution to complex groundwater challenges. Education, raising awareness, cooperation networks and stakeholder involvement are crucial factors in achieving successful, i.e. sustainable, resource regulation and management. An attempt to answer the above question is presented in the following section and some insights into the barriers to effective and sustainable groundwater management in South Africa are provided.

\section{Qualitative assessment of current groundwater management: Methods}

The following qualitative assessment of current groundwater management in South Africa is based on the results of a recent 


\begin{tabular}{|l|l|c|}
\hline \multicolumn{2}{|c|}{ Overview of the experts chosen to interview } \\
\hline \multirow{3}{*}{ Sector } & Agency / Organisation & $\begin{array}{c}\text { Number of } \\
\text { interviewees }\end{array}$ \\
\hline \multirow{3}{*}{ National government } & & 3 \\
\hline \multirow{4}{*}{ Research organisations } & National Office, Department of Water Affairs (DWA) & 1 \\
\cline { 2 - 3 } & Regional Office, DWA, Northern Cape & 1 \\
\cline { 2 - 3 } & University of the Witwatersand & 3 \\
\cline { 2 - 3 } & University of KwaZulu-Natal & 3 \\
\cline { 2 - 3 } & Council for Scientific and Industrial Research (CSIR) & 3 \\
\cline { 2 - 3 } & Water Research Commission (WRC) & 1 \\
\hline Conservation organisations & Cap-Net & 2 \\
\cline { 2 - 3 } & South African National Biodiversity Institute (SANBI) & 1 \\
\hline
\end{tabular}

qualitative study. The research was based on semi-structured interviews conducted with 18 South African experts in the fields of groundwater resources and ecosystem services during November/December 2009.

The experts that participated in the face-to-face interviews were selected to reflect several types of expertise and knowledge from different sectoral arenas: politics and administration, consulting, research and practical nature conservation (Table 1).

The use of semi-structured interviews was motivated by the clear advantages of this method. The openness and flexibility of the approach allow the interviewer to react to uncertain and unexpected interview situations. Additionally, open-ended questions allow the interviewer to obtain a deeper understanding of an individual's perception and experience by letting the interviewees focus on the issues they believe to be the most relevant (Mayring, 2003). Because of their qualitative nature, semi-structured interviews also posses great potential with respect to the interpretation of individuals' contributions in their appropriate social and political context. During the assessment phase the interview results were first classified into 4 main clusters comprising the key overall findings and subsequently a comparative analysis was conducted to structure the contents.

In addition to the semi-structured interviews, the experts were asked to rank the importance of several water management measures and tools so as to make water managers aware of future planning and controlling requirements.

\section{Results}

The interview results summarised here focus on some of the root causes and challenges of groundwater-related problems and implementation hurdles of existing policy legislations. The following 4 key findings represent the main issues highlighted in the interviews with regard to the challenges South Africa must overcome in order to achieve the sustainable management of groundwater resources and to transform theory into practice. The analysis put emphasis on all 3 'pillars' of sustainability, namely, society, economy and ecology.

\section{Key finding 1: Undervaluation of the importance and} significance of groundwater resources

A major complex of problems concerning the use of groundwater for domestic purposes and for irrigation schemes in South Africa exists in people's minds, which are often shaped by cultural and ethical patterns. South Africa's subsurface water resources are barely recognised as being a life-essential resource, and are only exploited during prolonged periods of drought. This undervaluation might be linked to the private status attributed to groundwater in the past (Roman common law) on the one hand, but also to the invisible nature of aquifer systems on the other hand. In the experts' opinion, some perceptions of groundwater resources are coupled to cultural and ethical goals and values. Subsurface water resources that belonged in the past to the owner of the land were used with hardly any governmental control or regular monitoring engagement and landowners had a right to dig or drill wells where required. The NWA changed access rights and water managers tried to make people aware of the new groundwater allocation regulations. To change people's understanding and behaviour often encounters resistance from groundwater users (e.g. farmers, municipalities). The attitude of groundwater users, the manner of usage and techniques were established and consolidated mostly across several generations. To effect the acceptance of new access rights is a deeply-rooted cultural issue which still needs to be considered. Farmers, for example, consider rainfall on their property as their own water and less as a public good. Accordingly, the interviewees pointed to the challenge faced by current water managers to establish and implement new approaches, management tools and to change perceptions of groundwater. It often takes decades until new approaches, legal restraints and management tools are accepted and adapted by groundwater users in terms of changing traditions and habits.

Further, most of the experts mentioned that groundwater has long been used in rural areas, especially in the arid and semi-arid parts of the country. Unfortunately, groundwater is often perceived as a 'poor man's resource', with groundwater mainly used for subsistence farming and sanitation purposes. People in these areas are often isolated and have less contact with scientists to be able to discuss groundwater management issues.

In general, the experts highlighted the fact that water managers, decision-makers and engineers in South Africa were traditionally trained to build and operate large-scale surface water infrastructure (e.g. dams, basin-transfer systems) - rather than to put emphasis on the 'hidden' resource. Hence, the development of groundwater techniques, drilling of wells and the science of hydrogeology were never a major part of South Africa's water sector. The interviewees argued that the role of groundwater must find acceptance in people's minds, and that it needs to be understood and adopted by water managers, engineers and policy makers - predominately at national level. 


\section{Key finding 2: Shortages of expertise and adequate data}

The second key finding concerned the shortfall in hydrogeological capacity of both human expertise and physical as well as socio-economic data related to groundwater resources, aquifer properties and linkages to human well-being. It was emphasised that human resources are lacking at all management levels - in national and regional offices. Important management positions remain unfilled or are taken up by people requiring further specialised training before they can deal appropriately with the challenges facing their respective positions. The responsible positions in governmental agencies are changing on a regular base which makes it difficult to reach a certain degree on consistency and routine. Technical and professional expertise is missing at the local level almost nationwide and groundwater management is currently uncoordinated. This can be traced back to the fact that there is neither strong leadership at national level nor a champion of groundwater at catchment level. Consequently, a clear direction is missing and the implementation of national water legislation is slow to non-existent. As a means to handle this problem, the experts claimed that a groundwater coordinator could play an important role in ensuring a greater understanding of the resource, management and control of the rates of extraction, and in educating local communities and end-users.

Due to the misallocation of roles and responsibilities, monitoring data upon which extraction policies and other regulations can be based is incomplete and an adequate evaluation of aquifer recharge, discharge and storage is lacking. Shortages of reliable groundwater data, and a very uneven distribution of information across the country, induce many misunderstandings related to the scale of aquifer systems, the distribution of groundwater resources and the timescales at which groundwater processes operate. The experts mentioned that there are some tools available to provide a better collection, evaluation and verification of groundwater in South Africa. The National Groundwater Database and the development of a National Groundwater Archive provide information related to boreholes and aquifer characteristics and hydrological data. Unfortunately, the quality of the data is very variable since there is a lack of complete borehole records and very few data characterising either the volumetric consumption of aquifers or the recharge and discharge of different aquifer types are available. Until now, South Africa has made little investment in an adequate monitoring infrastructure for aquifer systems compared to that for surface water resources. Therefore, most aquifer systems are underutilised and, when it occurs, extraction is uncontrolled.

In addition to the necessary hydrogeological data, it is extremely important that socio-economic information is also collected which plays a more subtle role related to poverty alleviation, health standards and social vulnerability. Some interviewees described this situation of expertise and data shortages as an impasse, as the existing institutional, political, social and economic systems fail to provide sufficient incentives for groundwater managers to intervene.

\section{Key finding 3: Centralisation of power}

The current management of groundwater by the national and regional offices of the DWA exhibits huge disparities in terms of the structures in place for cooperation between the different political agencies, administrative levels and other stakeholders. The experts identified horizontal and vertical integration structures within groundwater management as being the factors that determine the success or failure of management. The experts deemed the organising of linkages between different institutions with relatively autonomous yet interdependent actors to be central to preventing a fragmentation and separation of water management structures. Decentralised management systems may lead to greater efficiency, effectiveness and equity. In general, South Africa's water sector lacks these integration structures, both in terms of the exchange between responsible administrative levels and in terms of cooperation between different sectors such as agriculture, land use planning, nature conservation, forestry and society as a whole. Some of the experts highlighted the fact that, at national level especially, government regulators neither interact nor agree on the management of groundwater and the regulation of aquifer systems. They suggested that between certain sectors, even within the DWA, a high level of competition exists in terms of leadership, data exchange and evaluation responsibilities. Consequently, the existing hydrogeological information is managed in a highly uncoordinated manner and does not find application where necessary.

The involvement of stakeholders in decision-making processes and resource utilisation is mostly weak and barely acknowledged by groundwater managers and government agents. The movement towards 'bottom-up' approaches is crucial for the success of sustainable groundwater management but has received hardly any recognition in South Africa. Nevertheless, there are some sectors with access to organised meetings and communication networks allowing them to express their concerns to the national government; e.g., large farmers reliant upon irrigation and the mining sector. For the most part, however, the stakeholders are participants in informal groupings or isolated individuals such as rural farmers. These stakeholders have neither access to the relevant information nor can they afford to join meetings or participate in educational programmes. According to the experts, tailored regulation and tools to address local requirements are missing as there is hardly any discussion taking place between national government and individual stakeholders, and in many instances groundwater experts are unwilling to share information with the general public.

\section{Key finding 4: Disregard of groundwater ecosystems and associated goods and services}

Research into aquifer-dependent ecosystems and groundwater goods and services is subject to little attention in the overall context of management and these issues are, therefore, hardly recognised in the national water legislation. Ecological approaches are rare in groundwater management, and are only implemented to a certain degree (e.g., the Reserve). Water managers are often not aware of direct linkages between groundwater storage, recharge and discharge, or of the wide variety of marketable goods groundwater provides and supports (e.g., food production). Consequently, South Africa's groundwater resources tend to be used with scant regard for economic or other considerations, and the close linkages between groundwater and ecosystem services are mostly undervalued. In many instances the linkages, between the groundwater resources, the services they provide and human well-being, are not apparent, and because many benefits associated with groundwater are public goods, the economic value of groundwater often goes unrecognized. As a consequence, South Africa's groundwater resources tend to be used and managed with little or no regard for economic importance. 


\begin{tabular}{|c|c|}
\hline \multicolumn{2}{|r|}{$\begin{array}{l}\text { Table } 2 \\
\text { Expert ranking of groundwater management tools and measures }\end{array}$} \\
\hline Importance & Tools and measures \\
\hline \multirow[t]{6}{*}{ Very important } & Implementing existing groundwater legislation and regulations \\
\hline & Improving vertical cooperation structures between actors of different administrative levels \\
\hline & Improving horizontal cooperation between different sectors and agencies \\
\hline & Developing a nationwide information management system \\
\hline & Monitoring of sources of pollution (mining, agriculture, industry, urban waste, etc.) \\
\hline & $\begin{array}{l}\text { Developing an aquifer monitoring system and national database to store pertinent data } \\
\text { (recharge, discharge, stream flow, etc.) }\end{array}$ \\
\hline \multirow{11}{*}{$\begin{array}{l}\text { Moderately } \\
\text { important }\end{array}$} & Intensifying stakeholder involvement (society) \\
\hline & Raising awareness (society) \\
\hline & Education and training programmes (all stakeholders) \\
\hline & Developing new economic instruments \\
\hline & Implementing existing economic instruments \\
\hline & Changing land-use patterns and cropping systems \\
\hline & Implementing groundwater protection zoning \\
\hline & Opening up of new groundwater resources / exploiting new aquifer systems \\
\hline & Artificial recharging of aquifers / rainwater harvesting \\
\hline & Applying conjunctive use of surface- and groundwater \\
\hline & Developing groundwater models and scenario planning \\
\hline \multirow{2}{*}{$\begin{array}{l}\text { Of minor } \\
\text { importance }\end{array}$} & Formulating new groundwater legislation and regulations \\
\hline & Developing transboundary aquifer management systems \\
\hline
\end{tabular}

There is currently a widespread consensus in South Africa that the motivations, goals and values of groundwater-associated ecosystem services cannot be ignored in relation to water management. Ethical and cultural considerations in regard to human action and engagement of ecological processes and functions must become increasingly significant. Nonetheless, the experts highlight the fact that the groundwater services for industrial uses (e.g. water for farming and mining activities) are still preferred over groundwater services supporting ecological functions (e.g. baseflow to rivers and nutrient cycling). Often this situation results in a huge number of trade-offs. The most relevant management trade-offs identified by the experts are the emergence of alien vegetation due to a modified water balance and artificial water transport systems; the distribution of baseflow to rivers, springs and wetland systems; the pollution of soil and aquifer bodies due to contaminated agriculture and mining return-flows; and finally local competition between intensive irrigation schemes and natural water requirements. The analysis revealed the great necessity for research in areas characterised by commercial agriculture and mining activities, as these activities impact heavily upon groundwater-dependent ecosystems and the associated services. Furthermore, the interviewees stressed the significance of finding approaches to put a value on ecosystem services (e.g., taxes, tradable permits) so that water managers have the possibility to consider tradeoffs between all groundwater uses and users, on the one hand, and to put in place incentives for end-users to save water, on the other.

\section{Assessment of groundwater management tools and measures}

During the interview the experts were asked to classify the importance of future groundwater management measures in South Africa. Groundwater management tools are obviously important, as they provide incentives for managers and stakeholders to achieve a sustainable allocation of resources. Apart from economic instruments, which seek to prompt groundwater users to adopt a certain kind of behaviour voluntarily (Kemper at al., 2003), many management instruments relate to resource protection, such as aquifer monitoring and evaluation. Further measures include water legislation and regulatory provisions, the purpose of which should be to limit activities that might compromise water availability and quality, or to provide a legal basis for extraction rates and to stipulate user obligations (Nanni et al., 2003).

The experts ranked 19 management tools, ranging in magnitude from 'of no importance' to 'very important' over the next 10 to 15 years. The analysis revealed that the interviewees categorised all of the management tools as being of either minor, moderate or great importance. None of the measures were deemed to be unimportant. Table 2 provides an overview of all management tools and the importance attributed to them by the experts interviewed. All of the tools within a particular category of importance have the same weighting.

The most important management tools identified by the experts are highlighted in the following. Great importance was attached to the implementation of existing water legislation and groundwater regulations. Management approaches recognising the importance of information management were also deemed critical, as was the improvement of vertical and horizontal cooperation structures. Finally, the experts identified the need to develop adequate monitoring and pollution control systems as a very important means to detect general changes in groundwater flow and trends in groundwater quality, and hence to bridge gaps in scientific understanding of the resource base.

According to the interview results, the development and future application of groundwater management tools is hindered by an insufficient appreciation of the resource, shortcomings in knowledge and information, centralised system structures and an inadequate recognition of the significance of aquifer-dependent ecosystems and services. The outcome of the assessment reflected linkages between the key findings and the rankings attributed to the most important groundwater 
management tools, such as the need to develop cooperation structures and to collect adequate aquifer data on a regular basis.

The following recommendations have been derived from the results of the qualitative content analysis of the interviews, underlining the requirements in relation to groundwater management and providing instructions to water managers and policy makers.

\section{Recommendations}

Recommendations on how to transform current groundwater management, and the associated challenges, into more promising and sustainable practices have been formulated for South Africa's water managers on the basis of the results of the interview assessment. One must bear in mind that the sustainable management of groundwater resources is embedded in the specific socio-economic context and in the physical characteristics peculiar to each aquifer and groundwater problems are generally not amenable to rapid solution (Burke and Moench, 2000). An adequate level of aquifer characterisation and quantification is crucial in order to provide a scientific foundation for efficient and sustainable groundwater management (Foster, 2002).

However, moving from scientific knowledge to legislation and finally to implementation requires a paradigm shift in people's mindsets, and often this is not related to financial shortages or a lack of human capacity. Rather, groundwater must come to be seen as an integral part of water management and must be attributed a status equal to that of surface water. Furthermore, water managers need to recognise the complex linkages between hydrology, ecology, socio-economics, and cultural characteristics. The concept of adaptive water management presents a promising approach to enhancing and optimising current management in South Africa, and can serve to counter the existing difficulties and provide adequate solutions.

\section{Adaptive management}

The overall idea behind adaptive management builds upon the recognition of the fact that ecosystems are complex, adaptive and self-organising systems that must be managed in such a way that it is possible to adjust to changes or unexpected occurrences (Gunderson and Holling, 2001). A more encompassing interpretation of adaptive management was provided by PahlWostl et al (2010 p. 573): 'Adaptive management is a systematic process for improving management policies and practices by systemic learning from the outcomes of implemented management strategies and by taking into account changes in external factors in a pro-active manner.' It involves a well-planned iterative process of selecting and testing several scenarios and goals, and of assessing the responses to the corresponding management interventions (Rogers et al., 2000). Hence, adaptive management implies a 'learning by doing' approach, it considers uncertainties explicitly and it requires a basic rethinking of what management means in an uncertain and changing environment consisting of various complex systems (Pahl-Wostl et al., 2007). According to Maimone (2004), adaptive management represents the only approach available when dealing with uncertainties in knowledge and the variability of social attitudes to sustainable groundwater resources.

Given the historical development of groundwater management in South Africa, most management structures do not provide the structural conditions necessary to implement adaptive management approaches. The ability to implement adaptive management depends on a number of structural regime characteristics. One cannot easily move from a highly centralised groundwater system to polycentric and participatory management practices without changing certain structural conditions in the management arena. Essential requirements for a paradigm shift towards adaptive management in general include (Pahl-Wostl, 2008; UNEP, 2003):

- A shift towards participatory management and collaborative decision making, including both governmental and non-governmental actors at all levels

- Greater integration of different research issues and interdisciplinary sectors such as agriculture, water, tourism, environment, mining and forestry

- Decentralised and more flexible management approaches that take uncertainties and surprises into account

- The putting in place of widely accepted and clear water laws and rights or, in their absence, a practicable system of incentives

- The incorporation of ecological goals and values, and their inclusion in formal legislation to be implemented at all levels

- The provision of access to information, as well as the planned collection of data and monitoring of groundwater quality and quantity.

The next section presents guiding principles for management intended to facilitate a move towards adaptive management practices that are capable of coping with the dual pressures of: biophysical stressors, such as climate-related hazards; and meeting socio-economic demands for sustainable development in South Africa.

\section{Management response}

The South African groundwater governance regime to date has lacked the capacity for adaptive management. The essential requirements presented above are very rarely met in practice, their implementation can be difficult, and the move from conventional bureaucracies to adaptive structures is time consuming. Calls for a management response to groundwater use often only arise when there is a drastic decline in well yields or when water quality affects stakeholders. It is essential that it be recognised that managing groundwater resources is as much about managing people and includes cultural and ethical attitudes. In other words, the socio-economic dimension is as important as the hydrogeological dimension, and the integration of both is always required (Tuinhof et al., 2003b).

In order to achieve adaptive management, and indeed to make adaptive management possible, a number of longterm principles should be taken into account, thereby making improvements in the institutional arena of sustainable groundwater management and overcoming the key constraints outlined in the interview results. The principles build upon the philosophy of adaptive water management and include some management methods and tools which are assumed to support the integrated management goals as constituted in the NWA and NWRS. This mainly comprises a shift away from a technical management paradigm that is based primarily on centralised control and the building of hard physical infrastructure towards more open, participatory and polycentric management practices (Cots et al., 2009). Great emphasis, therefore, is placed on building a capacity for socio-economic and ecological resilience, as well as creating conditions for cooperation networks and bottom-up approaches.

One has to bear in mind that there are manifold opportunities, approaches and frameworks related to different actor 
Table 3

Methods and tools which can be used in network meetings (Ridder et al., 2005)

\begin{tabular}{|l|l|}
\hline $\begin{array}{l}\text { Name of method } \\
\text { or tool }\end{array}$ & Short description \\
\hline Brainstorming & Workshop setting focused on the collection of a large number of ideas on a specific subject \\
\hline Focus group & Group interviews with 6-10 people at the same time - to compare similarities and differences afterwards \\
\hline $\begin{array}{l}\text { Group model } \\
\text { building }\end{array}$ & Facilitated session in which participants build a model to improve their understanding of the issue/problem \\
\hline Interviews & Discussions, usually with open questions and the possibility of extensive answers \\
\hline $\begin{array}{l}\text { Problem / cause } \\
\text { analysis }\end{array}$ & In-depth analysis of causal network which is behind a problem \\
\hline $\begin{array}{l}\text { Public audience / } \\
\text { public hearing }\end{array}$ & $\begin{array}{l}\text { Meeting which presents the public with information and provides a forum for answering questions and } \\
\text { collecting opinions }\end{array}$ \\
\hline Role-playing game & Gaming situation in which players take certain roles in a real or imaginary context \\
\hline $\begin{array}{l}\text { Scenario building } \\
\text { Workshop setting in which policy options for the present and the immediate future are debated and their } \\
\text { possible consequences are explored }\end{array}$ \\
\hline
\end{tabular}

\begin{tabular}{|c|c|c|}
\hline \multicolumn{3}{|c|}{$\begin{array}{c}\text { Table } 4 \\
\text { Baseline and time-variant data for groundwater monitoring systems (adopted from } \\
\text { Tuinhof et al., 2003b) }\end{array}$} \\
\hline Type of data & Baseline data & Time-variant data \\
\hline $\begin{array}{l}\text { Groundwater occurrence } \\
\text { and aquifer properties }\end{array}$ & $\begin{array}{l}\text { - Water well records (hydrogeological } \\
\text { logs, water levels and quality) } \\
\text { - Well and aquifer pumping tests }\end{array}$ & $\begin{array}{ll}\text { - } & \text { Groundwater level monitoring } \\
\text { Groundwater quality } \\
\text { monitoring }\end{array}$ \\
\hline Groundwater use & $\begin{array}{ll}\text { - } & \text { Water well pump installations } \\
\text { - } & \text { Water use inventories } \\
\text { - } & \text { Population registers and forecasts } \\
\text { Energy consumption for irrigation }\end{array}$ & $\begin{array}{ll} & \text { Water well abstraction } \\
\text { monitoring } \\
\text { - Well groundwater level } \\
\text { variations }\end{array}$ \\
\hline Supporting information & $\begin{array}{ll}\text { - } & \text { Climatic data } \\
\text { - } & \text { Land-use patterns } \\
\text { - } & \text { Geological maps }\end{array}$ & $\begin{array}{ll} & \text { River-flow gauging } \\
\text { - } & \text { Meteorological observations } \\
\text { - } & \text { Satellite land-use surveys }\end{array}$ \\
\hline
\end{tabular}

groups and management goals. Here, the principles have been developed mainly for water managers and policy makers in South Africa, and seek to bring previously fragmented policy interventions under a unifying governance structure, including stakeholders from all relevant levels, and maintaining the ecosystem services provided by aquifer systems.

\section{Principle I: Change the negative overall perception of groundwater}

Change mindsets and make people aware of groundwater as a source of freshwater that is just as valuable as surface water and try to revise negative perceptions of subsurface resources by means of regular public awareness-raising campaigns, training and education programmes. The role and value of groundwater must be emphasised by managers and scientists by integrating groundwater into river basin management. An opportunity for policy makers and water managers would be to introduce the concept of 'conjunctive use', which is an expression to describe the complementary abstraction of surface and groundwater resources. This concept is strongly recommended for South Africa based on 2 main reasons, namely: the groundwater issue is more present in water management and hence in people minds; and due to climatic changes this concept offers an adaptive strategy to already-present surface water shortages.

Further, it is necessary to build strong cooperation networks in which people can meet, interact, exchange experiences and seek to achieve a new understanding of the benefits groundwater provides. This can help to broaden people's horizons and offers new opinions and solutions to a certain problem (e.g. access to water). Table 3 provides an overview of recommended methods and tools which can be used to build up or strengthen networks and meetings at a local scale, which are applicable to all education standards of the stakeholders.

These network meetings must include representatives of national government, CMAs, WUAs, local municipalities, NGOs and groundwater experts. Crucial to build up trust between the network co-operators are regular meetings, information exchange and access (socio-economic and ecological data), as well as technical and financial support by the government. The problems and concerns of individual stakeholders must be taken seriously and discussed in open meetings. Beside team building a further effect is to strengthen socio-economical interests. Successful farmers, for example, could introduce 'best-practices' and experiences to support emerging farmers.

\section{Principle II: Improve knowledge, skills and expand the existing database}

Education and awareness-raising are basic principles for adaptive and sustainable groundwater management. The widespread lack of information and data pertaining to groundwater is one of the underlying causes of many of the problems related to effective and sustainable management. Data is central to enhancing knowledge and capacity building with regard to groundwater skills (e.g., scientific education programmes, academic studies) and is also vital for the integration of groundwater in water management overall. The evaluation of groundwater issues and the implementation of appropriate management solutions requires, according to Tuinhof et al. (2003a), in particular, hydrogeological data which can be divided into 'baseline' and 'time-variant' components (Table 4). 
The development of aquifer monitoring systems, regular data evaluation and the designation of certain groundwater protection zones such as springs or wetlands will facilitate the incorporation of groundwater into efficient management approaches. An emphasis needs to be placed on local-scale examinations of groundwater datasets and on greater cognisance of local aquifer characteristics. In the long term it is crucial that the education of children becomes more important in order to shift society's awareness and understanding of groundwater problems and alternative management opportunities.

\section{Principle III: Develop strong leadership for improved communication and guidance}

Establish a strong groundwater leadership, coordinator or champion. The leadership can either be established for each WMA or a smaller unit (e.g. hydrogeological unit). This person will form a key link in local groundwater management both for planning and implementation processes. A good leadership is required to facilitate communication between all of the relevant stakeholders, sectors and governmental agencies, and to support information exchange between stakeholders and national governments; in other words, the groundwater coordinator gives a voice to everyone. Further leadership is required in order to provide practical instructions to implement national water legislation at local level. The groundwater champion should not be seen as the head or chief of groundwater management, rather he/she takes a 'control centre' role of communication and administration. Good leadership is indicated by the following attributes:

- Educated: a groundwater champion must understand hydrogeological mechanisms, socio-economic development, institutional and administrative groundwater regulations and must be able to link cross-cutting issues (e.g. agriculture, wastewater treatment, forestry, etc.) to aquifer management. Most important is understanding the linkages and interdependencies between these diverse components.

- Open: a groundwater champion must adopt an open attitude and does not make unilateral decisions; rather he/she must be open-minded and respect and support all stakeholders' goals and values in an integrative manner

- Flexible and adaptive: a groundwater champion must provide a high capacity to manage groundwater resources and by including the manifold interests of stakeholders in the catchment. Governing aquifer systems is concerned with learning how to avoid negative side-effects (e.g. water table drop, decrease of water quality). Hence, the leader must provide the ability to cope with and adapt to changing conditions in the catchment (e.g. micro-climate change).

- Trustful: a groundwater champion must build up trust between him/her and the stakeholders and between the stakeholders themselves. This is a core attribute especially in rural areas or small municipalities which did not experience much attention from the government in the past.

There are many more attributes related to a strong and efficient leader for groundwater resources. It is recommended for each area - proposed to have a groundwater champion - to take into account all goals, values, problems and possible solutions related to aquifer planning. First these issues must be addressed in regular meetings and subsequently a leadership must be chosen who is able to address the interests of the stakeholders in his/her catchment.

\section{Principle IV: Advocate local needs and bottom-up approaches}

Before initiating stakeholder meetings it must be clear who needs to be involved in groundwater management and local resource regulations. It is crucial to take into account diverse local water requirements and individual needs. The sustainable management of groundwater resources depends on decisions of numerous actors who have individual goals and values related to economic development, social welfare or ecological conservation - sustainable and efficient groundwater management needs, inter alia, a broad integration of bottom-up approaches by including a wide array of diverse stakeholders. According to Burke and Moench (2000), the following 4 groups should constitute the core group of active actors in terms of achieving systematic and adaptive groundwater management:

- Local stakeholders - water users and others whose interests are directly affected by groundwater management and whose actions often determine the effectiveness of any given initiative

- Policy makers (regional and national) - those who have the ability to influence the institutional arena within which management approaches must evolve

- Public sector organisations - these stakeholders often have their own internal agendas and control large programmes that have major impacts on groundwater resources

- Private sector organisations - these stakeholders are often major water users (e.g. agriculture or mining industries) whose interests may or may not coincide with those of local stakeholders

Correspondingly, it is strongly recommended to develop legal entities with clear mandates for self-regulation taken from government. Bottom-up approaches should be supported by the water services authorities, water boards and water services providers. Stakeholders' understanding of emerging problems often increases the scope of possible interventions. Hence, participation of the local people represents a critical starting point for management, but without excluding other regulatory, economic or technical avenues. The national government can promote bottom-up approaches by playing an active role in the mobilisation of people in local processes, providing funds and technical services for local initiatives, investing in infrastructure, building capacity and expertise among practitioners, and coordinating initiatives that span more than one local government (Bardhan, 2002). In order to develop bottom-up approaches water managers have to address some core questions assumed to be important for efficiency and success (according to Burke and Moench, 2000):

- What is the structure or context governing management attempts and approaches?

- Who needs to be involved (see core group of active actors)?

- Why is local regulation and management important?

- How are actions going to address real problems?

- When are actions going to take place?

It is recommended to develop for each WMA or hydrogeological unit a strategic management framework - based on individual and local requirements - to specify the linkages between context/structure (including social, cultural, economic and ecological characteristics), state of the aquifer system (including physical measurements), management approaches and development goals. Since social, economic and hydrological systems are dynamic rather than static, the framework must be flexible and adaptive. It must be possible to change certain 
approaches and goals without degrading the aquifers and dependent ecosystems, or, in other words, the framework needs to guide an iterative process through which emerging problems can be addressed and evolved. It further supports bottom-up approaches by assigning roles and responsibilities to local stakeholders. This indicates a clear structure of complex tasks and makes people feel significant and meaningful in what they do and what they can achieve.

\section{Principle V: Be aware of important ecosystem goods and functions that people obtain from aquifers}

Maintaining the health of groundwater systems implies considerable benefits for human well-being, economic growth and the conservation of biodiversity. Therefore it is crucial to investigate aquifer-dependent ecosystems and include a detailed assessment of groundwater-associated ecosystem services. As far as is possible, include an elaborate valuation approach for direct (e.g. monetary value) and indirect (cultural, religious or spiritual value) ecosystem services. Groundwater and associated ecosystem services tend to be undervalued in general. In particular, many of the social and cultural values associated with groundwater use are poorly reflected in markets. In the absence of a market price for groundwater services it is recommended to measure its value through the users' willingness to pay for a given quantity and quality of supply. For industrial usage of groundwater services it is recommend to establish efficient and adequate water markets which require clear, enforceable (and often private) property rights, high levels of information availability, minimal externalities, low transaction costs, feasible competition, and clear definite 'solutions of continuity' (Burke and Moench, 2000). Several economic tools are available to stimulate an economic actor (groundwater user) to voluntarily adopt a certain behaviour which aims to reach a more efficient and sustainable groundwater allocation (e.g. stabilise groundwater levels by reducing over-abstraction, diminishing the risk of negative impacts and social conflicts, and delaying the need for investment in alternative water resources). According to Kemper et al. (2003) some important economic instruments to support sustainable groundwater (ecosystem) management are:

- Modification to agriculture and food trade policies

- Subsidies to encourage real water-saving measures

- Subsidies for use of more efficient irrigation technology to decrease agrochemical leaching

- Subsidies for industries/municipalities to implement appropriate water treatment technologies

The most important element to make economic instruments work in South Africa is to ensure enforcement and the assignment of responsibilities and roles including bottom-up approaches and the establishment of strong leadership (see Principles III and IV).

In summary, education, information, cooperation networks, leadership, ecological awareness and the establishment of adequate groundwater markets are cornerstones on which governance and the implementation of South Africa's groundwater management will operate and upon which the requirements of the NWA will be effectively implemented. Therefore, groundwater managers must establish a holistic approach to their thinking in order to cope with future uncertainties, such as water scarcity, water pollution and the impacts of global climate change, in order to implement sufficiently the NWA, NWRS and groundwater guidelines.

\section{Conclusions and outlook}

Given the very critical nature of the water situation in South Africa, it is vital that groundwater issues feature on national and regional management agendas. Groundwater makes up the bulk of freshwater supply and provides many different ecosystem services to support socio-economic and ecological systems. Current water management mechanisms and policies in South Africa do not take into consideration the full potential of subterranean water resources and the contribution they make to human well-being. Although South Africa's water legislation includes groundwater resources as an integral part of the hydrological cycle, and offers unique and flexible set-ups to fulfil the requirements of the National Water Act, the implementation is weak and hardly realised in the 19 WMAs of the country.

The aim of this research was to identify major challenges facing sustainable and adaptive groundwater management in South Africa and gaps towards the practical implementation of policy legislation. Many of these challenges lie in the domain of cooperation structures within institutional and political agencies. Existing governance systems, and their performance, are characterised by knowledge gaps and a scarcity of the necessary data pertaining to aquifers. National and local governments need to undertake coordinated and interdisciplinary action to: minimise the adverse impacts of anthropogenic activities; protect sensitive aquifer-dependent ecosystems and associated ecosystem services; facilitate access to freshwater to meet basic needs; and introduce and support bottom-up approaches by considering individual goals and values.

It is concluded that water managers and policy makers need to make the adaptive water management approach a high priority as a means to overcome the challenges facing groundwater and to improve the existing structures in the political arena. Accordingly, principles were set out to assist in the implementation of adaptive water management. It is crucial that the principles are consistent with ecological and socio-economic requirements and diverse stakeholders' goals and values.

It is strongly recommended that the social, cultural, ethical, and economic dimension is considered to be as important as the technical and physical dimension in the evolution and implementation of management approaches and tools, to ensure that all 3 sustainability pillars, society, economy and ecology, are addressed, and to fulfil the principles of equity, efficiency and sustainability as defined in the National Water Act of South Africa.

South Africans with a stake in groundwater issues must be made aware of the many benefits they derive from healthy aquifer systems. By recognising the many advantages groundwater provides to human well-being, people may treat and manage subsurface water resources in a more sensitive manner and experience the many benefits groundwater has to offer.

\section{Acknowledgments}

The author would like to thank all experts and their willingness to participate in the interviews by providing meaningful insights and information. Special thanks goes out to the Collaboration Project: Initiative Bilateral Cooperation in Science and Technology, SA/Germany funded by the South African National Research Foundation and the Federal Ministry of Education and Research of Germany. Further the author thanks Carolin Rettig (Institute of Environmental Systems Research, University of Osnabrück) for reading early 
drafts of the manuscript and for providing very helpful and constructive input.

\section{References}

ASHTON P, BRAUNE E, MAAREN H, McKENZIE RS, ORPEN WRG, PITMAN W, ROOSEBOOM A, SCHULZE RE, VAN ROOYEN PG and VAN VUUREN SJ (1999) Hydrological science in South Africa: 1995-1998. S. Afr. J. Sci. 95 259-268.

BAKKER K, KOOY M, SHOFIANIA NE and MARTIJN EJ (2008) Governance failure: rethinking the institutional dimensions of urban water supply to poor households. World Dev. 36 (10) 1891-1915.

BARDHAN P (2002) Decentralization of governance and development. J. Econ. Perspect. 16 (4) 185-205.

BGR (BUNDESANSTALT FÜR GEOWISSENSCHAFTEN UND ROHSTOFFE) (2008) Groundwater and climate change: challenges and possibilities. BGR, Hannover.

BRAUNE E (2000) Towards comprehensive groundwater resource management in South Africa. IAH Congress 2000, 10-12 March 2000, Cape Town.

BRAUNE E and REYNDERS AJ (1998) Past achievements and future challenges for groundwater in South Africa. GEOCONGRESS 98 , 7-10 July 1998, Pretoria, South Africa.

BRAUNE E and XU Y (2008) Groundwater management issues in southern Africa - an IWRM perspective. Water SA 34 (6) 699-706.

BRAUNE E and XU Y (2009) The role of groundwater in Sub-Saharan Africa. Ground Water 48 (2) 229-238.

BROMLEY J, CRUCES J, ACREMAN M, MARTÍNEZ L and LLAMAS MR (2001) Problems of sustainable groundwater management in an area of over-exploitation: The Upper Guadiana Catchment, Central Spain. Int. J. Water Resour. Dev. 17 (3) 379-396.

BURKE J and MOENCH M (2000) Groundwater and society: resources, tensions and opportunities. Themes in groundwater management for the twenty-first century. United Nations Department of Economic and Social Affairs, New York, USA.

COLVIN C and SAAYMAN I (2007) Challenges to groundwater governance: a case study of groundwater governance in Cape Town, South Africa. Water Polic. 9 (2) 127-148.

COTS F, TÀBARA JD, MCEVOY D, WERNERS S and ROCA E (2009) Cross-border organisations as an adaptive water management response to climate change: the case of the Guadiana river basin. Environ. Plann. C: Gov. Polic. 2009 (27) 876-893.

COUNCIL OF CANADIAN ACADEMIES (2009) The sustainable management of groundwater in Canada. Expert Panel on Groundwater, Report to the Government of Canada.

CUSTODIO E and LLAMAS MR (2001) Intensive use of groundwater: introductory considerations. In: Llamas R and Custodio E (eds.) Intensive Use of Groundwater-Challenges and Opportunities. Swets \& Zeitlinger BV, Lisse, The Netherlands.

DAILY GC (1997) Nature's Services - Societal Dependence on Natural Ecosystems. Island Press, Washington.

DANIELOPOL D, GRIEBLER C, GUNATILAKA A and NOTENBOOM J (2003) Present state and future prospects for groundwater ecosystems. Environ. Conserv. 30 (2) 104-130.

DWAF (DEPARTMENT OF WATER AFFAIRS AND FORESTRY, SOUTH AFRICA) (2002) A groundwater mapping strategy for South Africa. Directorate: Geohydrology, Department of Water Affairs and Forestry, Pretoria.

DWAF (DEPARTMENT OF WATER AFFAIRS AND FORESTRY, SOUTH AFRICA) (2004a) National Water Resource Strategy. First edn. Department of Water Affairs and Forestry, Pretoria.

DWAF (DEPARTMENT OF WATER AFFAIRS AND FORESTRY, SOUTH AFRICA) (2004b) Groundwater Resource Assessment II Task 1D Groundwater identification. Department of Water Affairs and Forestry, Pretoria.

FAO (FOOD AND AGRICULTURE ORGANIZATION) (2003) Groundwater management - The search for practical approaches. FAO, Rome.

FOSTER S (2002) Thailand: strengthening capacity in groundwater resources management. World Bank Case Profile Collection 1. World Bank.
GUNDERSON L and HOLLING CS (2001) Panarchy: Understanding Transformations in Systems of Humans and Nature. Island Press, Washington, D.C.

IPCC (INTERGOVERNMENTAL PANEL ON CLIMATE CHANGE) (2008) Climate change and water. IPCC Technical Paper VI. URL: http://www.ipcc.ch/pdf/technical-papers/climate-change-water-en. pdf (Accessed 10 December 2009).

KEMPER K, FOSTER S, GARDUNO H, NANNI M and TUINHOF A (2003) Economic instruments for groundwater management: using incentives to improve sustainability. World Bank Briefing Note 7. World Bank.

KUNDZEWICZ ZW and DÖLL P (2009) Will groundwater ease freshwater stress under climate change? Hydrol. Sci. 54 (4) 665-675.

LOUCKS DP (2000) Sustainable water resources management. Water Int. 25 (1) 3-10.

MAIMONE M (2004) Defining and managing sustainable yield. Ground Water 42 (6) 809-814.

MAYRING P (2003) Qualitative Inhaltsanalyse - Grundlagen und Techniken. Beltz Verlag, Weinheim und Basel.

MUKHEIBIR P and SPARKS D (2005) Climate variability, climate change and water resource strategies for small municipalities. WRC Report No. K5/1500. Water Research Commission, Pretoria.

MUKHERJI A and SHAH T (2005) Groundwater socio-ecology and governance: a review of institutions and policies in selected countries. Hydrogeol. J. 13 328-345.

MULLER M (2009) Attempting to do it all: how South Africa has harnessed water to address its development challenges. In: Lenton $\mathrm{R}$ and Muller M (eds.) Integrated Water Resources Management in Practice - Better Water Management for Development. Earthscan, London. 169-185.

MÜNCH Z and CONRAD J (2007) Remote sensing and GIS based determination of groundwater dependent ecosystems in the Western Cape, South Africa. Hydrogeol. J. 15 19-28.

MURRAY K, DU PREEZ M and MEYER R (2007) National microbial monitoring programme for groundwater. WRC Report No. TT 312/07. Water Research Commission, Pretoria.

NANNI M, FOSTER S, DUMARS C, GARDUNO H, KEMPER K and TUINHOF A (2003) Groundwater legislation and regulatory provision: from customary rules to integrated catchment planning. World Bank Briefing Note 4. World Bank.

NYENJE PM and BATELAAN O (2009) Estimating the effects of climate change on groundwater recharge and baseflow in the upper Ssezibwa catchment, Uganda. Hydrol. Sci. J. 54 (4) 713-726.

PAHL-WOSTL C, SENDZIMIR J, HEFFREY P, AERTS J, BERKAMP G and CROSS K (2007) Managing change toward adaptive water management through social learning. Ecol. Soc. 12 (2) 30. URL: http://www.ecologyandsociety.org/vol12/iss 2/ art30/ (Accessed June 09, 2009).

PAHL-WOSTL C (2008) Requirements for adaptive management., In: Pahl-Wostl C, Kabat P and Möltgen J (eds.) Adaptive and Integrated Water Management - Coping with Complexity and Uncertainty. Springer Publishers, Berlin, Heidelberg.

PAHL-WOSTL C, HOLTZ G, KASTENS B and KNIEPER C (2010) Analyzing complex water governance regimes: The management and transition framework. Environ. Sci. Pol. 13 571-581.

PARSONS R and TREDOUX G (1995) Development of a strategy to monitor groundwater quality on a national scale in South Africa. Hydrogeol. J. 3 (1) 50-56.

REPUBLIC OF SOUTH AFRICA (1998) National Water Act (Act No. 36 of 1998). Government Printers, Pretoria, South Africa.

RIDDER D, MOSTERT E and WOLTERS HA (2005) Learning Together to Manage Together - Improving Participation in Water Management. University of Osnabrück, Germany.

ROGERS K, ROUX DJ and BIGGS H (2000) Challenges for catchment management agencies: lessons from bureaucracies, business and resource management. Water SA 26 (4) 505-511.

ROGERS P and HALL AW (2007) Effective water governance. TEC Background Papers No. 7. Global Water Partnership, Stockholm.

SEWARD P, XU Y and BRENDONCK L (2006) Sustainable groundwater use, the capture principle, and adaptive management. Water $S A 32$ (4) 473-282. 
SEWARD P (2010) Challenges facing environmentally sustainable ground water use in South Africa. Ground Water 48 (2) 239-245.

SCHULZE RE (2005) Looking into the future: Why research impacts of possible climate change on hydrological responses in Southern Africa? In: Schulze RE (ed.) Climate Change and Water Resources in Southern Africa: Studies on Scenarios, Impacts, Vulnerabilities and Adaptation. WRC Report No. 1430/1/05. Water Research Commission, Pretoria.

TREDOUX G, ENGELBRECHT JFP and ISRAEL S (2009) Nitrate in groundwater. Why is it a hazard and how to control it? WRC Report No. TT 410/09. Water Research Commission, Pretoria.

TUINHOF A, DUMARS C, FOSTER S, KEMPER K, GARDUNO $\mathrm{H}$ and NANNI M (2003a) Groundwater resource management: an introduction to its scope and practice. Briefing Note 1. World Bank.

TUINHOF A, FOSTER S, KEMPER K, GARDUNO H and NANNI $M$ (2003b) Groundwater monitoring requirements for managing aquifer response and quality threats. World Bank Briefing Note 9. World Bank.

TURTON A, GODFREY L, JULIEN F and HATTINGH H (2006) Unpacking groundwater governance through the lens of a trialogue: a Southern African case study. Proc. International Symposium on Groundwater Sustainability (ISGWAS), 24-27 January 2006, Alicante, Spain.

UNEP (UNITED NATIONS ENVIRONMENTAL PROGRAMME)

(2003) Groundwater and its susceptibility to degradation - a global assessment of the problem and options for management. Early Warning and Assessment Report Series RS. 03-3. United Nations Environment Programme, Nairobi, Kenya.

VAN TONDER G (1999) Groundwater management under the new National Water Act in South Africa. Hydrogeol. J. 7 421-422.

VAN WYK E, BREEN CM, ROUX DJ, ROGERS KH, SHERWILL T and VAN WILGEN BW (2006) The ecological Reserve: towards a common understanding for river management in South Africa. Water SA 32 (3) 403-410.

WARD RC and ROBINSON M (1990) Principles of Hydrology. McGraw Hill Book Company, London.

WORLD WATER COUNCIL (2006) Water resources development in Africa. Africa Regional Document. 4th World Water Forum, 16-22 March 2006, Mexico. Comision Nacional del Agua, Mexico. 
Available on website http://www.wrc.org.za ISSN 0378-4738 (Print) = Water SA Vol. 37 No. 1 January 2011 